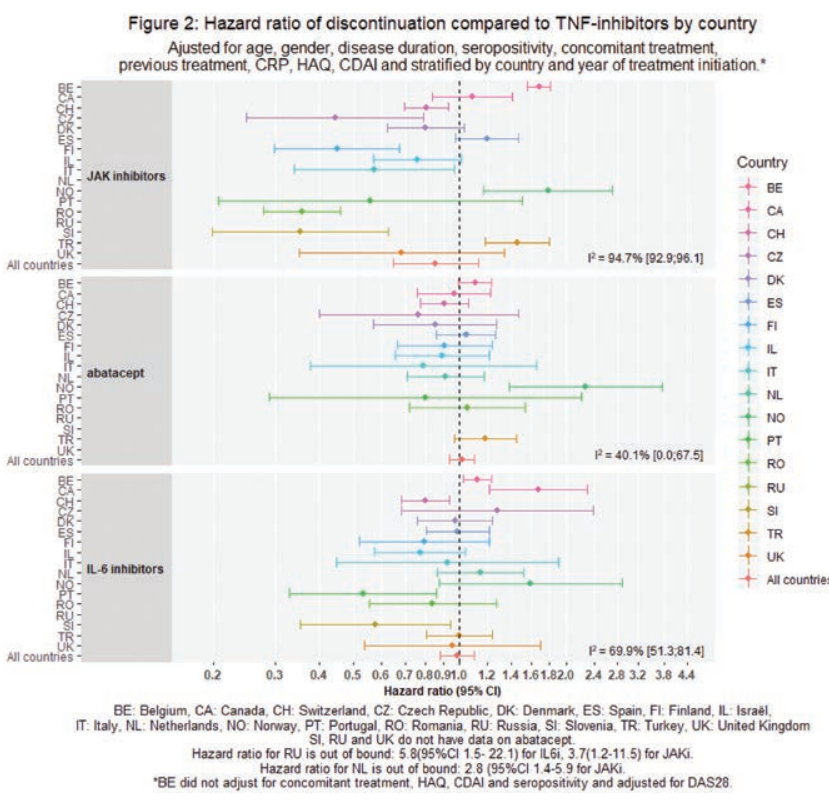

Conclusion: The adjusted overall drug retention of JAKi tended to be higher than for TNFi, with large variation between countries. Other measures of effectiveness, such as the evaluation of CDAI remission and low disease activity are planned to shape a more comprehensive picture of JAKi effectiveness in the real world.

Disclosure of Interests: Kim Lauper: None declared, Denis Mongin: None declared, Sytske Anne Bergstra: None declared, Denis Choquette Grant/research support from: Rhumadata is supported by grants from Pfizer, Amgen, Abbvie, Gylead, BMS, Novartis, Sandoz, eli Lilly,, Consultant of: Pfizer, Amgen, Abbvie, Gylead, BMS, Novartis, Sandoz, eli Lilly,, Speakers bureau: Pfizer, Amgen, Abbvie, Gylead, BMS, Novartis, Sandoz, eli Lilly,, Catalin Codreanu Consultant of: Speaker and consulting fees from AbbVie, Accord Healthcare, Alfasigma, Egis, Eli Lilly, Ewopharma, Genesis, Mylan, Novartis, Pfizer, Roche, Sandoz, UCB, Speakers bureau: Speaker and consulting fees from AbbVie, Accord Healthcare, Alfasigma, Egis, Eli Lilly, Ewopharma, Genesis, Mylan, Novartis, Pfizer, Roche, Sandoz, UCB, Diederik De Cock: None declared, Lene Dreyer: None declared, Ori Elkayam Speakers bureau: AbbVie, BMS, Pfizer, Roche, Sanofi-Aventis, Novartis, Jansen, Kimme Hyrich Grant/research support from: Pfizer, UCB, BMS, Speakers bureau: Abbvie, Florenzo lannone Consultant of: Speaker and consulting fees from AbbVie, Eli Lilly, Novartis, Pfizer, Roche, Sanofi, UCB, MSD, Speakers bureau: Speaker and consulting fees from AbbVie, Eli Lilly, Novartis, Pfizer, Roche, Sanofi, UCB, MSD, Nevsun Inanc: None declared, Eirik kristianslund: None declared, Tore K. Kvien Grant/research support from: Received grants from Abbvie, Hospira/Pfizer, MSD and Roche (not relevant for this abstract)., Consultant of: Have received personal fees from Abbvie, Biogen, BMS, Celltrion, Eli Lily, Hospira/Pfizer, MSD, Novartis, Orion Pharma, Roche, Sandoz, UCB, Sanofi and Mylan (not relevant for this abstract)., Paid instructor for: Have received personal fees from Abbvie, Biogen, BMS, Celltrion, Eli Lily, Hospira/Pfizer, MSD, Novartis, Orion Pharma, Roche, Sandoz, UCB, Sanofi and Mylan (not relevant for this abstract)., Speakers bureau: Have received personal fees from Abbvie, Biogen, BMS, Celltrion, Eli Lily, Hospira/Pfizer, MSD, Novartis, Orion Pharma, Roche, Sandoz, UCB, Sanofi and Mylan (not relevant for this abstract)., Burkhard Leeb Grant/research support from: chairman of BioReg, Consultant of: AbbVie, Pfizer, Roche, Lilly, Grünenthal, Gebro,, Paid instructor for: Lilly, Biogen, Speakers bureau: Biogen, Lilly, Pfizer, Grünenthal, Astropharma,, Galina Lukina Speakers bureau: Novartis, Pfizer, UCB, Abbvie, Biocad, MSD, Roche, Dan Nordström Consultant of: Abbvie, Celgene, Lilly, Novartis, Pfizer, Roche and UCB., Speakers bureau: Abbvie, Celgene, Lilly, Novartis, Pfizer, Roche and UCB., Karel Pavelka Consultant of: Abbvie, MSD, BMS, Egis, Roche, UCB, Medac, Pfizer, Biogen, Speakers bureau: Abbvie, MSD, BMS, Egis, Roche, UCB, Medac, Pfizer, Biogen, Manuel Pombo-Suarez Consultant of: Janssen, Lilly, MSD and Sanofi., Speakers bureau: Janssen, Lilly, MSD and Sanofi., Ziga Rotar Consultant of: Speaker and consulting fees from Abbvie, Amgen, Biogen, Eli Lilly, Medis, MSD, Novartis, Pfizer, Roche, Sanofi., Speakers bureau: Speaker and consulting fees from Abbvie, Amgen, Biogen, Eli Lilly, Medis, MSD, Novartis, Pfizer, Roche, Sanofi., Maria Jose Santos Speakers bureau: Novartis and Pfizer, Anja Strangfeld Speakers bureau: AbbVie, BMS, Pfizer, Roche, Sanofi-Aventis, Delphine Courvoisier: None declared, Axel Finckh Grant/research support from: Pfizer: Unrestricted research grant, Eli-Lilly: Unrestricted research grant, Consultant of: Sanofi, AB2BIO, Abbvie, Pfizer, MSD, Speakers bureau: Sanofi, Pfizer, Roche, Thermo Fisher Scientific

DOI: 10.1136/annrheumdis-2020-eular.346

\section{OP0232 TREATMENT WITH METHOTREXATE AND RISK OF LUNG DISEASE IN PATIENTS WITH RHEUMATOID ARTHRITIS: A NATIONWIDE POPULATION-BASED COHORT STUDY FROM DENMARK}

E. Helene Ibfelt ${ }^{1}$, R. Kart Jacobsen ${ }^{2}$, T. I. Kopp ${ }^{3}$, R. Cordtz ${ }^{4}$, A. Svarre Jakobsen $^{5}$, N. Seersholm 6 , S. Burhan Shaker ${ }^{6}$, L. Dreyer ${ }^{4,7} .{ }^{1}$ Steno Diabetes Center, Gentofte, Denmark; ${ }^{2}$ Bispebjerg and Frederiksberg Hospital, Frederiksberg, Denmark; ${ }^{3}$ Rigshospitalet, Copenhagen, Denmark; ${ }^{4}$ Aalborg University Hospital, Aalborg, Denmark; ${ }^{5}$ Fures $\varnothing$ Reumatologerne, Farum, Denmark; ${ }^{6} \mathrm{Herlev}$ and Gentofte University Hospital, Hellerup, Denmark; ${ }^{7}$ DANBIO Registry, Denmark, Denmark

Background: Methotrexate (MTX) is the recommended first-line drug in EULAR and ACR treatment guidelines for rheumatoid arthritis (RA) and hence the most commonly prescribed DMARD in the treatment of this group of patients. However, lung disease is considered a potential adverse effect of MTX treatment.

Objectives: To investigate the risk of interstitial lung disease (ILD) and acute and chronic respiratory failure in RA patients treated with MTX and other medications. Methods: From the Danish National Patient Register (DNPR) and the clinical DANBIO Register for rheumatic diseases, we retrieved data on RA patients registered between 1997 and 2015. Information on ILD and respiratory failure outcomes was obtained from DNPR, and information on redeemed prescriptions for MTX and other medications was obtained through linkage to the Danish Prescription Register. Associations between MTX and lung disease outcomes were analyzed in Cox regression models adjusted for age, calendar time, sex and use of other medications possessing the potential for pulmonary toxicity. Standardized Incidence Ratios (SIRs) of lung disease were calculated to compare RA patients to the general population.

Results: Of the 30,512 RA patients identified, $60 \%$ patients had redeemed at least one prescription for MTX, 35\% had redeemed a prescription for sulphasalazine, $6 \%$ had redeemed a prescription of either amiodarone or

Table. Hazard ratios (HR) with $95 \%$ confidence intervals $(95 \% \mathrm{Cl})$ for the risk of interstitial lung disease (ILD) and acute or chronic respiratory failure in 30,512 patients with rheumatoid arthritis up to 5 years after diagnosis.

\begin{tabular}{|c|c|c|c|c|}
\hline \multirow[t]{2}{*}{ ILD (incl. drug-induced cases) } & \multicolumn{2}{|c|}{1 year of follow up } & \multicolumn{2}{|c|}{5 years of follow up } \\
\hline & Events, $\mathrm{N}$ & $\mathrm{HR}(95 \% \mathrm{Cl})$ & Events, $\mathrm{N}$ & HR $(95 \% \mathrm{Cl})$ \\
\hline Methotrexate, $\geq 1$ redeemed prescription(s) vs. none & 62 & $1.03(0.71$ to 1.48$)$ & 166 & $1.00(0.78$ to 1.27$)$ \\
\hline Sulphasalazine, $\geq 1$ redeemed prescription(s) vs. none & 21 & $0.88(0.54$ to 1.43$)$ & 90 & $1.14(0.89$ to 1.48$)$ \\
\hline Amiodarone and/or nitrofurantoin, $\geq 1$ redeemed prescription(s) vs. none & 1 & $0.57(0.08$ to 4.10$)$ & 7 & $0.65(0.31$ to 1.38 \\
\hline Women & 72 & Ref. & 155 & Ref. \\
\hline Men & 55 & $1.51(1.06$ to 2.16$)$ & 130 & $1.74(1.38$ to 2.21$)$ \\
\hline \multirow[t]{2}{*}{ Acute or chronic respiratory failure } & \multicolumn{2}{|c|}{ 1-year of follow up } & \multicolumn{2}{|c|}{5 -years of follow up } \\
\hline & Events, $\mathrm{N}$ & $\mathrm{HR}(95 \% \mathrm{Cl})$ & Events, $\mathrm{N}$ & HR $(95 \% \mathrm{Cl})$ \\
\hline Methotrexate, $\geq 1$ redeemed prescription(s) vs. none & 36 & $0.48(0.32$ to 0.73$)$ & 158 & $0.54(0.43$ to 0.67$)$ \\
\hline Sulphasalazine, $\geq 1$ redeemed prescription(s) vs. none & 14 & $0.70(0.39$ to 1.26$)$ & 99 & 1.09 (0.86 to 1.38$)$ \\
\hline Amiodarone and/or nitrofurantoin, $\geq 1$ redeemed prescription(s) vs. none & 6 & 3.01 (1.31 to 6.94$)$ & 22 & 1.33 (0.86 to 2.06$)$ \\
\hline Women & 71 & Ref. & 239 & Ref. \\
\hline Men & 38 & $1.07(0.72$ to 1.59$)$ & 120 & $1.04(0.83$ to 1.29$)$ \\
\hline
\end{tabular}


nitrofurantoin, and $27 \%$ had not received any of the included drugs at the end of the 5-year follow-up for ILD and respiratory failure. MTX treatment was not associated with an increased risk of lung disease ( $\geq 1$ redeemed prescription(s) compared to no prescriptions), HR 1.00 (95\% Cl 0.78 to 1.27$)$ for ILD and 0.54 $(95 \% \mathrm{Cl} 0.43$ to 0.67$)$ for respiratory failure at 5 -year follow-up (Table). The SIR was 3-4 times increased for ILD in MTX-treated RA patients, but this was no different from the RA population in general compared to the background population.

Conclusion: RA patients had an increased risk of ILD compared to the general population, but that risk was not further increased in patients treated with MTX compared to non-MTX treated.

Disclosure of Interests: None declared

DOI: 10.1136/annrheumdis-2020-eular.1609

\section{OP0233 EFFICACY, SAFETY, AND PHARMACODYNAMIC EFFECTS OF THE BRUTON'S TYROSINE KINASE INHIBITOR, FENEBRUTINIB (GDC-0853), IN MODERATE TO SEVERE SYSTEMIC LUPUS ERYTHEMATOSUS IN A PHASE 2 CONTROLLED STUDY}

D. Isenberg ${ }^{1}$, R. Furie ${ }^{2}$, N. S. Jones ${ }^{3}$, P. Guibord ${ }^{4}$, J. Galanter $^{3}$, C. Lee ${ }^{3}$, A. Mcgregor ${ }^{3}$, B. Toth ${ }^{3}$, J. Rae ${ }^{3}$, O. Hwang ${ }^{3}$, A. Lokku ${ }^{4}$, P. Miranda ${ }^{5}$, V. De Souza $^{6}$, J. Jaller-Raad ${ }^{7}$, A. Maura Fernandes ${ }^{8}$, R. Garcia Salinas ${ }^{9}$, L. Chinn ${ }^{3}$ M. J. Townsend ${ }^{3}$, A. Morimoto ${ }^{3}, \mathrm{~K}$. Tuckwell ${ }^{3} .{ }^{1}$ University College London, London, United Kingdom; ${ }^{2}$ Division of Rheumatology, Northwell Health, Great Neck, United States of America; ${ }^{3}$ Genentech, Inc., South San Francisco, United States of America; ${ }^{4}$ Hoffmann-La Roche Limited, Mississauga, Canada; ${ }^{5}$ Centro Estudios Reumatologicos, Santiago, Chile; ${ }^{6}$ Centro Mineiro de Pesquisas, Juiz de Fora, Brazil; ${ }^{7}$ Centro de Reumatologia y Ortopedia, Cimedical, Barranquilla, Colombia; ${ }^{8}$ Mario Covas Hospital, Santo Andre, São Paulo, Brazil; ${ }^{9} \mathrm{Hospital}$ Italiano de La Plata, Argentina, Argentina

Background: Fenebrutinib (GDC-0853, FEN) is an oral, non-covalent, and selective inhibitor of Bruton's tyrosine kinase (BTK) in clinical development for autoimmune diseases.

Objectives: This was a randomized, placebo-controlled, multi-center study to evaluate the efficacy, safety, and pharmacodynamic effects of FEN in patients with moderate-to-severe systemic lupus erythematosus (SLE) activity.

Methods: Patients who met SLICC or revised ACR SLE criteria, had $\geq 1$ serologic marker of SLE, SLEDAI $\geq 8$, and were on $\geq 1$ standard of care (SOC) therapy were included; patients with renal or CNS involvement, or exposure to B cell depleting or calcineurin inhibitor therapy were excluded. Patients were randomized to placebo (PBO), FEN $150 \mathrm{mg} \mathrm{QD}$, or FEN $200 \mathrm{mg}$ BID, for 48 weeks. A corticosteroid taper was recommended, with burst and taper permitted from Week 0 (W0) to W12 and W24 to W36. The primary endpoint was SRI-4 at W48. Post hoc subgroup analyses were conducted based on patient baseline disease characteristics.

Results: This study enrolled 260 patients, with the majority recruited in Latin America, USA, and Western Europe. At W48, the SRI-4 response rates for FEN $150 \mathrm{mg}$ QD and FEN $200 \mathrm{mg}$ BID were $51 \%$ (95\% Cl: -8.5, 21.2; p value 0.37 ) and $52 \%(95 \% \mathrm{Cl}:-7.3,22.4 ; \mathrm{p}$ value 0.34$)$, respectively, compared to $44 \%$ for PBO (Table 1). Post-hoc analysis showed larger responses in subgroups of patients with higher baseline disease activity (Table 1). Safety results were similar between FEN and PBO arms, although more serious adverse events were observed in the FEN $200 \mathrm{mg}$ BID arm. Study discontinuations were balanced across the 3 arms (24-26\%). FEN treatment significantly reduced levels of CD19+ B cells, anti-dsDNA autoantibodies, IgG, and a BTK-dependent RNA signature highly expressed in plasmablasts by W48 compared to PBO; C4 levels modestly improved with FEN vs. PBO (Table 2).

Table 1. SRI-4 Response (\%) at W48 in Primary Analysis and in Post-hoc Patient Subgroups

\begin{tabular}{|c|c|c|c|}
\hline & PBO & FEN $150 \mathrm{mg}$ QD & FEN $200 \mathrm{mg}$ BID \\
\hline \multirow[t]{2}{*}{ SRI-4 Response (\%) at W48 } & 44 & 51 & 52 \\
\hline & $n=84$ & $n=87$ & $n=88$ \\
\hline \multicolumn{4}{|l|}{ SRI-4 Response (\%) in Baseline Subgroups } \\
\hline \multirow[t]{2}{*}{ At least 1 BILAG A } & 48 & 54 & 59 \\
\hline & $n=42$ & $n=39$ & $n=46$ \\
\hline At least 1 BILAG A and SLEDAI & 37 & 53 & 65 \\
\hline increased DNA binding & $n=19$ & $n=17$ & $n=26$ \\
\hline SLEDAI arthritis with at least 4 swollen & 39 & 50 & 57 \\
\hline joints & $n=57$ & $n=54$ & $n=54$ \\
\hline SLEDAI arthritis with at least 4 tender & 39 & 53 & 59 \\
\hline joints & $n=71$ & $n=70$ & $n=69$ \\
\hline \multirow[t]{2}{*}{ CLASI $>=10$} & 21 & 36 & 31 \\
\hline & $n=14$ & $n=11$ & $n=16$ \\
\hline
\end{tabular}

Table 2. Key Biomarker Results

\begin{tabular}{|c|c|c|c|}
\hline & PBO & FEN $150 \mathrm{mg}$ QD & FEN $200 \mathrm{mg}$ BID \\
\hline \multicolumn{4}{|c|}{ Median (\%) Change from Baseline at W48 } \\
\hline \multirow[t]{2}{*}{ Plasmablast signature } & $-19.7 \%$ & $-54.3 \% *$ & $-51.7 \% *$ \\
\hline & $n=52$ & $n=53$ & $n=57$ \\
\hline \multirow[t]{2}{*}{ CD19+ B cells $($ cells $/ \mu \mathrm{l})$} & -0.50 & $-57.0^{\star}$ & $-57.5^{\star}$ \\
\hline & $n=38$ & $n=49$ & $n=48$ \\
\hline \multirow[t]{2}{*}{ Anti-dsDNA ${ }^{\#}(\mathrm{IU} / \mathrm{ml})$} & +6.9 & $-38.3^{*}$ & $-75.7^{\star}$ \\
\hline & $n=31$ & $n=36$ & $n=33$ \\
\hline \multirow[t]{2}{*}{ Total IgG (g/L) } & -0.20 & $-1.25^{\star}$ & $-1.56^{\star}$ \\
\hline & $n=65$ & $n=64$ & $n=64$ \\
\hline \multirow[t]{2}{*}{ C3 (g/L) } & -0.02 & +0.01 & -0.01 \\
\hline & $n=65$ & $n=67$ & $n=66$ \\
\hline \multirow[t]{2}{*}{ C4 (g/L) } & 0.00 & $+0.02^{*}$ & $+0.01^{*}$ \\
\hline & $n=65$ & $n=67$ & $n=66$ \\
\hline
\end{tabular}

\#Patients who were positive at baseline $(>30 \mathrm{IU} / \mathrm{mL})$

${ }^{*}$ Denotes significant vs. PBO; Kruskal-Wallis false-discovery rate controlled two sided ( $p$-value $\leq 0.05)$

Conclusion: The primary endpoint of SRI-4 for FEN was not met despite evidence of strong BTK target and pathway inhibition. FEN had an acceptable safety profile. Several disease activity subgroups were suggestive of a greater treatment effect on SRI-4 compared to PBO

Disclosure of Interests: David Isenberg Consultant of: Study Investigator and Consultant to Genentech, Richard Furie Grant/research support from: AstraZeneca, Biogen, Consultant of: AstraZeneca, Biogen, Nicholas S. Jones Shareholder of: Genentech/Roche, Employee of: Genentech/Roche, Pascal Guibord Shareholder of: Roche, Employee of: Roche, Joshua Galanter Shareholder of: Genentech/Roche, Employee of: Genentech/Roche, Chin Lee Shareholder of Genentech/Roche and Eli Lilly, Employee of: Genentech/Roche, Anna McGregor Employee of: Genentech/Roche, Balazs Toth Shareholder of: Genentech Roche, Employee of: Genentech/Roche, Julie Rae Shareholder of: Genentech/ Roche, Employee of: Genentech/Roche, Olivia Hwang Shareholder of: Genentech/Roche, Employee of: Genentech/Roche, Armend Lokku Shareholder of: Roche, Employee of: Roche, Pedro Miranda Consultant of: Study Investigator for Genentech, Viviane de Souza Consultant of: Study investigator for Genentech, Juan Jaller-Raad Consultant of: Study investigator for Genentech, Anna Maura Fernandes Consultant of: Study investigator for Genentech, Rodrigo Garcia Salinas Consultant of: Study investigator for Genentech, Leslie Chinn Shareholder of: Genentech/Roche, Employee of: Genentech/Roche, Michael J. Townsend Shareholder of: Genentech/Roche, Employee of: Genentech/Roche Alyssa Morimoto Shareholder of: Genentech/Roche, Employee of: Genentech/Roche, Katie Tuckwell Shareholder of: Genentech/Roche, Employee of Genentech/Roche

DOI: 10.1136/annrheumdis-2020-eular.2949

\section{\begin{tabular}{|l|l}
\hline OP0234 MBS2320, A NOVEL SELECTIVE MODULATOR OF \\
\hline
\end{tabular} IMMUNE METABOLISM, IN PATIENTS WITH SEVERE RHEUMATOID ARTHRITIS: SAFETY, TOLERABILITY AND EFFICACY RESULTS OF A PHASE 2 STUDY}

L. Patel ${ }^{1}$, L. Skillern ${ }^{1}$, M. Foster ${ }^{1}$, A. Gray ${ }^{1}$, R. Leff ${ }^{2}$, S. Williams ${ }^{1} .{ }^{1} /$ stesso Ltd, London, United Kingdom; ${ }^{2}$ Richard Leff LLC, Philadelphia, United States of America

Background: Despite the availability of several treatment options for Rheumatoid Arthritis (RA), many patients are classed as 'non-responders' who show little or no improvement. Hence, there remains a need for new therapies with a differentiated mechanism of action, to be used alone or in combination. MBS2320 is a selective modulator of immune metabolism displaying distinctive dual pharmacology: strong anti-inflammatory activity as well as a broader spectrum of osteoprotection than TNFa inhibition in preclinical models ${ }^{1}$.

Objectives: To evaluate the safety, tolerability and efficacy of MBS2320 in patients receiving a stable dose of methotrexate (MTX).

Methods: Patients with active RA on a stable dose of MTX were randomised 2:1 to receive MBS2320 (80mg) or matching placebo once daily for 4 weeks. Subject to a satisfactory safety and tolerability assessment, patients were escalated to a dose of $120 \mathrm{mg}$ qd or remained on $80 \mathrm{mg}$ qd for a further 8 weeks. Safety, efficacy, pharmacokinetics and pharmacodynamics were evaluated.

Results: 121 patients were randomised (Safety analysis set) to MBS2320 or matching placebo and 96 completed the study. Sixteen subjects were excluded from the efficacy analysis set due to evidence of poor compliance or absence of efficacy evaluations. Enrolled patients were mostly female (86.8\%), white and with a mean (range) age at baseline (BL) of 52 (19-69) years.

The study population had hard-to-treat, severe, active and erosive disease as indicated by high BL DAS28-CRP and DAS28-ESR, low Week-12 placebo ACR50 and DAS28-CRP responder rates (2.5\% and $5 \%$ respectively) and a low ratio of synovitis-to-erosion volume despite treatment with $\operatorname{DMARD}(\mathrm{s})$ 